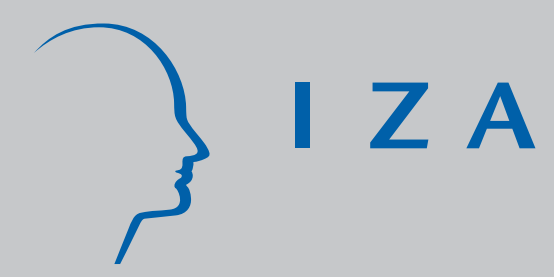

IZA DP No. 2114

The Impact of Brazil's Tax-Benefit System on Inequality and Poverty

Herwig Immervoll

Horacio Levy

J osé Ricardo Nogueira

Cathal O'Donoghue

Rozane Bezerra de Siqueira

May 2006 


\title{
The Impact of Brazil's Tax-Benefit System on Inequality and Poverty
}

\author{
Herwig Immervoll \\ ISER, University of Essex and IZA Bonn \\ Horacio Levy \\ ISER, University of ESSex \\ José Ricardo Nogueira \\ Universidade Federal de Pernambuco, Recife \\ Cathal O'Donoghue \\ National University of Ireland, Galway and IZA Bonn \\ Rozane Bezerra de Siqueira \\ Universidade Federal de Pernambuco, Recife
}
Discussion Paper No. 2114
May 2006
IZA
P.O. Box 7240
53072 Bonn
Germany
Phone: $+49-228-3894-0$
Fax: +49-228-3894-180
Email: iza@iza.org

\begin{abstract}
Any opinions expressed here are those of the author(s) and not those of the institute. Research disseminated by IZA may include views on policy, but the institute itself takes no institutional policy positions.

The Institute for the Study of Labor (IZA) in Bonn is a local and virtual international research center and a place of communication between science, politics and business. IZA is an independent nonprofit company supported by Deutsche Post World Net. The center is associated with the University of Bonn and offers a stimulating research environment through its research networks, research support, and visitors and doctoral programs. IZA engages in (i) original and internationally competitive research in all fields of labor economics, (ii) development of policy concepts, and (iii) dissemination of research results and concepts to the interested public.
\end{abstract}

IZA Discussion Papers often represent preliminary work and are circulated to encourage discussion. Citation of such a paper should account for its provisional character. A revised version may be available directly from the author. 


\section{ABSTRACT \\ The Impact of Brazil's Tax-Benefit System on Inequality and Poverty}

The Brazilian government raises taxes amounting to 35\% of GDP and spends more than two thirds of this on social programmes. These shares are in pair with the OECD averages and well in excess of Latin America averages. However, while tax-benefit systems in most OECD countries reduce income disparities very significantly, the Brazilian government has been much less successful in alleviating inequality and poverty. Focussing on taxes and cash transfers, this paper investigates the impact of the government budget on the income distribution in Brazil, and evaluates its efficiency and effectiveness in reducing inequality and poverty. We present BRAHMS, a new tax-benefit microsimulation model for Brazil and illustrate its use by evaluating the impact of policy on economic inequality. It is argued that microsimulation provides a valuable analytical tool for policy makers in emerging and developing countries in particular.

JEL Classification: $\quad \mathrm{H} 22, \mathrm{H} 23, \mathrm{C} 81$

Keywords: Brazil, inequality, poverty, redistribution, microsimulation

Corresponding author:

Horacio Levy

ISER University of Essex

Wivenhoe Park

Colchester CO4 3SQ

United Kingdom

Email: hlevy@essex.ac.uk

"This is a revised version of a paper presented at a 2005 conference on "Poverty, Inequality, and Policy in Latin America" in Göttingen, Germany. The paper was written as part of the project "Evaluating the Brazilian tax-benefit system using an integrated micro-simulation model", financed by United Nations Development Programme (UNDP). We wish to thank Kenneth Harttgen and two anonymous referees for comments on an earlier version. The usual disclaimer applies. In particular, the opinions expressed in this paper do not represent the official positions of the organisations to which the authors are affiliated. 


\section{INTRODUCTION}

Despite raising an amount of taxes equivalent to 35 per cent of the country's GDP and spending about seventy per cent of that on social programmes - a proportion close to the OECD average and well above the average in other Latin American countries ,Brazil has not been able to significantly alleviate inequality and poverty. Income inequality remains one of the highest in the world and more than a fifth of the Brazilian population still live below US\$2.00 a day (UNDP, 2005).

Brazil is an exception to the observed international pattern, where higher tax burdens are generally associated with lower income inequality. Figure 1 shows that the Gini coefficient in the United Kingdom and Spain is lower than in Brazil despite a similar tax burden. On the other hand, countries with relatively similar degrees of inequality, such as Mexico and Chile, have a much lower tax burdens.

To an extent, the lower income inequality in developed countries reflects the impact of tax-benefit systems. For instance, taking the Gini coefficient of market income inequality as a starting point, Immervoll et al (2006) estimate that taxes and benefits reduce income inequality by $36 \%$ on average across 15 European Union (EU) countries. Clearly, accounting for the redistributive impact of the government budget is crucial when looking for explanations for observed differences in income inequality.

This paper quantifies the direct impact of tax burdens and benefit payments on inequality and poverty in Brazil. Our analysis uses BRAHMS, a newly developed taxbenefit microsimulation model that generates detailed information on taxes and benefits paid and received by households in a representative sample of the Brazilian population.

The paper is structured in six sections. Section 2 discusses the microsimulation approach as a tool for analysing the redistributive properties of social and fiscal policies. Section 3 describes the scope and main features of BRAHMS and discusses the quality of the model results. Section 4 considers some conceptual and methodological issues concerning the measurement of the inequality, redistribution and poverty efficiency. Section 5 presents the relevant income distribution measures derived from the BRAHMS model and uses these results to discuss the role of a number of existing policy measures. Section 6 concludes.

\section{The Microsimulation Approach ${ }^{1}$}

Representative microdata are widely used for both national and international studies on the redistributive effects of taxes and benefits. ${ }^{2}$ However, available microdata generally present important limitations for the scope of these studies as the quality and level of detail of the data are not always as needed. For studying the distributive properties of taxes and benefits, the most severe shortcoming is that household micro-data often simply do not contain information on certain types of taxes or benefits, or not at the required level of detail, For instance, different transfers may be aggregated into one single variable, making it impossible to capture the effects of each underlying policy.

\footnotetext{
${ }^{1}$ In this paper we draw on the experience of the development and use of the EU-wide tax-benefit microsimulation model (EUROMOD). See Immervoll, et al. (1999), Sutherland (2001) and http://www.iser.essex.ac.uk/msu/emod for more information on EUROMOD.

${ }^{2}$ For example, Förster and Mira d'Ercole (2005) report household income inequality before and after taxes and social benefits based on microdata from 27 OECD countries.
} 
A number of income surveys do not contain any information on income taxes or social security contributions at all. Given that redistribution is one of the primary objectives of taxation, this is of course a serious limitation. The microdata we use for this study share this limitation. One attraction of microsimulation modelling is that it can overcome some of these data restrictions and therefore provide a more suitable basis for studying distributional issues.

\subsection{Microsimulation Modelling}

Rather than relying on tax and benefit amounts recorded in the data, microsimulation (or "tax-benefit") models calculate tax liabilities and benefit entitlements by combining data on each household's characteristics with detailed institutional information on the functioning of tax and benefit policies. This is done in accordance with legal rules to ensure that results for each observation correspond as closely as possible to the taxes and benefits that would be determined by tax authorities and benefit agencies.

These models calculate each element of the tax-benefit system in the legal order so that interactions between different elements of the system are accounted for. By incorporating the interactions of different elements of the tax-benefit system and by taking full account of the heterogeneity of the population, this approach allows a very detailed analysis of the revenue, distributional and incentive effects of individual policy instruments as well as the tax-benefit system as a whole.

Tax-benefit microsimulation models provide a rich basis for assessing the distributive impact of taxes and benefits. The most obvious advantage of this approach is that it permits an analysis of taxes and benefits that may not be directly observed in the microdata. The simulation approach also provides greater analytical flexibility, as it allows categories of taxes and benefits to be defined independently of definitions adopted by the data providers. For instance, individual transfers can be analysed even if the underlying data only provide less detailed benefit aggregates.

Most often, microsimulation models are used to evaluate the effects of policy reforms. ${ }^{3}$ By changing relevant parameters of the tax-benefit algorithms (e.g. tax rates or benefit entitlement rules), one can compute alternative measures of taxes, benefits and net incomes, and compare the results for all observations with those of some baseline system (such as the existing tax-benefit system of a particular year). The arithmetic difference between the two scenarios is then one useful indication of the impact of the reform and can be presented in terms of revenue effects, inequality measures or the number of "gainers" and "losers". These types of results can inform reform debates, making relevant trade-offs more transparent and decisions more accountable.

The analysis of policy reforms is also the primary purpose of the BRAHMS microsimulation model. However, this paper uses this model to analyse existing policy configurations. Evaluations of reform scenarios, which we leave for future work, can then draw on these results as a useful counterfactual.

\subsection{Microsimulation Modelling in Developing Countries}

While a large number of governments and institutions have been utilising this technique in developed countries for some time, there is still limited use in emerging economies.

\footnotetext{
${ }^{3}$ See www.iser.essex.ac.uk/msu/emod/ for recent examples of European studies.
} 
Yet the potential benefits of these techniques appear particularly attractive in the case of developing countries. Because of the greater degrees of poverty and tight public finance positions, effective and efficient tax-benefit policy design is essential and can potentially make a very considerable difference to individuals’ wellbeing.

Atkinson and Bourguignon (1990) carried out a study of the lessons of tax-benefit modelling in OECD countries for emerging economies. They found that although often more difficult to implement, simulating tax-benefit systems for these countries should "lead to a comprehensive, powerful and yet simple instrument for the design of an efficient redistribution system adapted to the specificity of developing countries".

Atkinson and Bourguignon's paper set the scene for the construction of tax-benefit models for developing countries. Here we go beyond this and actually develop and apply a prototype version of a microsimulation model for Brazil. The next section explains this model in further detail.

\section{A TAX-Benefit Microsimulation Model For Brazil}

Due to the very heterogeneous Brazilian population and the complexity of tax-benefit rules, the study of the redistributive effect of social and fiscal policies requires considerable level of detail. Ultimately, it is the interaction between the socio-economic and demographic characteristics of the population and the taxes and benefits that determine the effect of the fiscal system on income redistribution.

In this study we implement and use a prototype version of the tax-benefit microsimulation model for Brazil: the Brazilian Household Microsimulation System (BRAHMS). Both the data and the policy rules relate to the year 2003. In this preliminary version the model simulates personal direct taxes and cash transfers using micro-data from the National Household Survey (Pesquisa Nacional por Amostra de Domicílios - PNAD).

The most important characteristics of cash benefits and direct taxes are summarised below and in Table A1 in the appendix. ${ }^{4}$ Monetary figures are expressed as a proportion of the national minimum wage (MW). In 2003, the MW amounted to 240 reais per month which corresponds to approximately 25\% of the average wage. 240 reais are equivalent to US\$ 129 in purchasing power parities.

\subsection{Social Benefits}

The benefit system is strongly based on contributory social insurance benefits, while means-tested social assistance programmes occupy a marginal position. Pensions alone account for $85 \%$ of total cash transfers to households, or about 11\% of GDP (see Table

\footnotetext{
${ }^{4}$ While these account for a considerable share of the government budget, there are of course other policies which also have important distributional effects, in particular indirect taxes and non-cash benefits (such as health and education). Extending BRAHMS to account for these latter two types of policy is subject to ongoing work. In a previous paper (Immervoll et al, 2003), we have presented a partial analysis of the distributional effect of indirect taxes. The study concluded that the regressive effect of indirect taxes cancels out the progressive effect of direct taxes, so that the total redistributive effect of taxes was estimated to be approximately neutral. However, measures of the incidence of indirect taxes in terms of current income tend to overestimate the regressivity of these taxes. Siqueira, Nogueira and Souza (2000) estimated the incidence of indirect taxes for Brazil based on consumption.
} 
A1). This percentage is above the OECD average, despite Brazil's much younger population.

\section{Pensions}

There are two main public pension systems in Brazil: a general regime for private sector workers and multiple special regimes for civil servants at different government levels. Both systems are mandatory and of the pay-as-you-go type.

- Public pensions for private-sector workers

The scheme for private sector workers pays retirement benefit under two main circumstances. The first is the old-age pension, which is paid to male (female) urban workers aged 65 (60) who have contributed for at least 15 years. Alternatively, retirement benefits are paid to those who accumulated 35 (for men) and 30 (for women) years of contribution, without age limit requirements.

Rural workers are only required to provide evidence of 15 years of rural activities to be eligible for a minimum pension at age 60 (for men) or 55 (for women), regardless of previous contributions. In fact, rural pensions can be considered as part of social assistance, because they are essentially non-contributory.

Pension amounts are subject to a ceiling and floor. The ceiling is the same as the cap applying to the contribution base of social contributions (about $8 \mathrm{MW}$ ). The floor is equal to the MW with about 60\% currently paid at this lowest level. In 2003, about 18 million people receive a private sector pension. More than a third of these received a pension under the "rural" scheme.

- Civil servants’ pensions

Special schemes for civil servants exist at different levels of government. These schemes differ from each other in terms of contribution rates, but in almost all cases they are significantly more generous than the scheme for private sector workers. For instance, male civil servants retiring at the age of 60 (55 for female workers) with 35 years of contribution (30 for female workers), are entitled to pensions equal to $100 \%$ of their last salary, without a cap. ${ }^{5}$

In fact, average public sector pensions in the federal government are seven times higher than for those in the private workers regime. In 2004, the civil servant regimes accounted for about $14 \%$ of total pensioners and $40 \%$ of total pension expenditure.

- Annual bonus for pensioners

All pensioners, both in the private sector and in the civil service, receive an extra payment equal to one monthly pension payment.

\footnotetext{
${ }^{5}$ A reform enacted in 2003 reduced the replacement rate for civil servants, but the new rule applies only to new civil servants. .
} 


\section{Contributory benefits for private-sector workers}

These benefits are paid to insured private sector workers. Entitlement can be subject to an individual earnings test, irrespective of the economic condition of the household in which the person lives. Benefits under this heading account for about $11 \%$ of total cash benefits.

- Unemployment insurance benefit (seguro desemprego)

Unemployed workers may receive this benefit for up five months. The amount is determined as a proportion of the average salary received during the three months before unemployment with a benefit floor of MW and a ceiling slightly below 2 MW. In 2003, about 5 million people received unemployment benefits.

- Salary bonus (abono salarial)

This consists of a yearly payment equal to MW to formal-sector workers with a monthly salary below 2 MW. In 2003, the programme benefited a total of 7.8 million workers.

- Family benefit (salário família)

This benefit is paid to employees with children who earn up to about 2 MW. The monthly benefit amount is about $6 \%$ of MW for each child under the age of 14 (or disabled of any age). In 2003, this programme covered approximately 5 million children .

- Other insurance-based benefits

There are a number of other insurance-based benefits such as maternity, sick leave and accident insurance are not analyzed in this study due to lack of data. In 2003, about 2 million people received these benefits.

\section{Non-contributory means-tested benefits}

These income support programmes are targeted to individuals living in families with income below a certain threshold. Above the threshold, benefits are stopped abruptly rather than being withdrawn gradually. In other words, all eligible individuals receive the full benefit amount. In 2003 these programmes represented about 4\% of all cash transfers.

- Old-age and disability assistance benefits

These benefits consist of the payment of a minimum wage per month to low-income individuals who are either above 65 or disabled. The low-income threshold is $25 \%$ of MW per capita. In 2003, more than 2.3 million people benefited from this programme. 


\section{- School attendance benefit (Bolsa-Escola)}

This means-tested child benefit is paid to families with per capita income below about $40 \%$ of MW and children aged 6 to 15 who are attending school. The value of the benefit is approximately 6\% of MW (15 reais) per child with a maximum benefit per family of 45 reais. In 2003, about 5 million families received this benefit.

- Other non-contributory means-tested benefits

There are a number of other non-contributory means-tested benefits such as Bolsa Alimentação, Cartão Alimentação and Auxílio-Gás. These are not analyzed in this study due to insufficient data.

\subsection{Taxes and social contributions}

Total tax revenues amounted to 35\% of GDP in 2003. Personal and corporate income taxes raise about $18 \%$ of the revenue. It is estimated that personal income tax revenue accounts for about half of that. Social insurance contributions account for $18 \%$, other payroll taxes for 6\%, indirect taxes (including VAT) for nearly one-third and property taxes for $3 \%$. The remainder of tax revenue (about 23\%) is mainly raised by turnover taxes.

\section{Employee's social security contribution}

Contribution rates for private sector employees range from 7.6 to $11.0 \%$, and are subject to a cap equivalent to almost $8 \mathrm{MW} .{ }^{6}$ Rural workers contribute under a special scheme based on the degree of commercialisation of agricultural products (these contributions cover only about $14 \%$ of rural pensions expenditure).

Civil servant contribution rates vary across government levels. Federal civil servants contribute at a rate of $11 \%$. Contributions are very different across state governments. Overall, the rates range between $6 \%$ and $14 \%$.

It is worth noting that in 2003, less than half the labour force paid social security contributions. The combined deficit of the publicly managed social security schemes is about 5\% of GDP, which is financed out of taxes based on turnover.

\section{Personal Income Tax}

In 2003, all residents were required to file income tax returns if their annual taxable income exceeded an exemption limit equivalent to 4.4 MW. Taxable income includes earnings, property income, pensions and earnings-related contributory benefits. Investment income, maintenance transfers, means-tested benefits and unemployment benefits are not subject to income tax.

Personal income tax is levied at the individual level. However, taxpayers can also file jointly and benefit from a deduction (about 44\% of MW) for each dependent relative. ${ }^{7}$

\footnotetext{
${ }^{6}$ Employers contribute a flat $20 \%$ without cap.

7 These include spouses, children aged under 22 (or 25 when in education), and other relatives with taxable income below the exemption limit.
} 
There are also tax allowances for public and private insurance contributions, educational and medical expenses. Alternatively, these itemised allowances can be replaced by a standard deduction equivalent to $20 \%$ of taxable income. The tax schedule consists of two bands. The marginal tax rate is $15 \%$ above the exemption limit and $27.5 \%$ for taxable income above twice the exemption limit.

Given the high degree of income inequality, the relatively generous exemption threshold, and the size of the informal sector, only about $23 \%$ of the economically active population pay income tax.

\subsection{Data}

In this study we use data from the 2003 National Household Survey (Pesquisa Nacional por Amostra de Domicílios - PNAD). PNAD is the main socio-economic household survey in Brazil. This cross-sectional survey is representative of rural and urban populations at both the national regional levels with the exception of the rural area in the North (Amazonian region). The 2003 sample consists of 133,255 households and 384,834 individuals.

The information collected takes September 2003 as the month of reference. ${ }^{8}$ The data provide detailed information on socio-demographic and labour market information relevant for calculating tax burdens and benefit entitlements. For example, the survey distinguishes between workers who are and are not registered in the social security system or affiliated to a trade union. This information is essential for capturing the degree of tax evasion and the eligibility to insurance benefits. Incomes are reported at the monthly level before taxes and contributions (gross). Original earnings data do not include extra payments, bonuses and earnings-related benefits. Instead, we impute them according to the legislation for employees in the formal sector (see Section 3.1 above).

PNAD identifies recipients of unemployment benefits and Bolsa Escola although no information on the benefit amount is available. These are therefore calculated according to the legal rules using BRAHMS. The database does not distinguish the three different types of pension schemes (civil servants, insurance private employees, and old-age assistance). Like most cross-sectional household surveys, PNAD also does not include data on individual labour market history which would be needed for simulating pension entitlements. In the distributional analysis below, information on pension incomes is therefore read from the data rather than simulated using BRAHMS.

There is no direct information in PNAD about the amount of personal income tax or social security contribution payments. Both types of tax liabilities are therefore simulated using BRAHMS. The underlying simulation assumptions are described in the next sub-section.

\footnotetext{
${ }^{8}$ In October 2003, Bolsa Escola and other three federal social assistance benefits (Bolsa Alimentação, Cartão Alimentação and Auxílio-Gás were amalgamated into one: Bolsa Família. Since it was implemented after the databases month of reference (September 2003) there is no information about this new programme in the PNAD. Bolsa Família is expected to be analysed in future versions of BRAHMS using more recent data.
} 


\subsection{Scope of simulations and underlying assumptions}

As a static microsimulation model, BRAHMS calculates current taxes, benefits and net incomes based on personal and household characteristics reported in the underlying micro data.

To account for the large number of informal worker, income taxes and contributions are only computed for individuals who are shown to be members of the social security scheme or affiliated to a trade union. All other individuals reporting employment or self-employment income are assumed to belong to the informal sector and pay no taxes. Municipal civil servants are all assumed to pay the same social contributions rate as the PNAD data does not allow us to distinguish between municipalities. Simulated contributory benefits are also conditional on membership in the social security scheme. Regarding the take-up of means-tested benefits, it is assumed that all entitled workers receive Salary Bonus and Family Benefit. Information about the actual receipt of Bolsa Escola and Unemployment Benefit is taken directly from data (see Section 3.3).

The simulations assume that individuals choose the tax and benefit options that maximise the disposable income at the family level. Therefore, family members choose the taxation scheme (individual or joint) and tax allowances that minimise the income tax liability of the family (see Section 3.2).

\subsection{Validation}

The first step of validating the results of a microsimulation model is to ensure that rules are correctly coded. This has been done by comparing the output of the model against manually calculated taxes and benefits for a large number of hypothetical families, such as singles and couples with and without children, in different employment situations and at different earnings levels.

In a second step, the model is applied to each family in the PNAD sample and results are then compared to relevant reference statistics. When interpreting the match between model results and external reference information, it is essential to keep in mind known shortcomings on either side. For instance, there is limited reference statistics on income tax and family benefit; PNAD is not representative of the rural area in the North region,, and the model relies on assumptions regarding tax evasion and benefit take-up).

Comparisons of BRAHMS output against a number of official "headline" statistics are shown in Table A2 in the appendix. In general, the estimates compare reasonably well with available reference statistics. Observed deviations are in line with those found for tax-benefit models in other countries and attributable to the data limitations and assumptions described above ${ }^{9}$. More detailed validation-related data can be obtained from the authors.

\footnotetext{
${ }^{9}$ See, for example, the EUROMOD country reports- http://www.iser.essex.ac.uk/msu/emod/countries/.
} 


\section{Measuring the Distributional EfFEcts of TAXes AND BenEFits}

\subsection{Inequality and redistribution}

We measure the distributional effects of different tax-benefit policies using indices derived from the Lorenz Curve. ${ }^{10}$ The Lorenz Curve is a graph of the cumulative population share versus the cumulative income share with observations ranked in ascending order of their income:

$$
L_{X}(p)=\int_{0}^{y} \frac{x \cdot f(x) d x}{\mu} \forall 0<\mathrm{p}<1, \mathrm{~L}(0)=0, \mathrm{~L}(1)=1
$$

where $f(x)$ is the frequency density function that is positive at all income levels, $\mu$ is the average income, and $p$ is the population share ranging from 0 to 1 ; for each $p$ there is a unique income level $y$, so that $p=F(y)$.

The Lorenz curve is useful for comparing income distributions. If the Lorenz curve of distribution $F$ is always above the Lorenz curve of distribution $G$ then distribution $F$ is less unequal than distribution $G$ in any case. However if the Lorenz curves cross, it is not possible to obtain inequality rankings without further value judgments.

The Gini coefficient is a standard index of inequality directly derived from the Lorenz curve:

$$
G_{X}=1-2 \int_{0}^{1} L_{X}(p) d p
$$

It can be decomposed into a weighted sum of concentration coefficients of the various income components in order to show the relative contribution of each to overall income inequality:

$G_{X}=\sum_{k=1}^{m} \frac{\bar{X}_{k}}{\bar{X}} C_{k}$

where $\bar{x}$ is average 'total' income, $\bar{x}_{k}$ is the average value of income component $k$, and $C_{k}$ is the concentration coefficient with observations ranked in ascending order of 'total' income $x$. The concentration coefficient thus expresses how unequal the income component $k$ is distributed across 'total' income groups. The higher the concentration coefficient $C_{k}$ or the share of the most unequally distributed (or "concentrated") components, the larger the Gini coefficient of 'total' income inequality. ${ }^{11}$

\footnotetext{
10 The methods described here are standard tools of income distribution analysis. See, for example, Palme, 1996, and Creedy, 1997.

${ }^{11}$ Despite its simplicity and attractiveness, this approach is not exempt from problems. In the case of an income component $k$ that is constant for all income units, its concentration coefficient will be zero. Therefore, contrary to the general view that that an addition of a constant to all incomes decreases total inequality, this approach would lead us to conclude that component $k$ does not make any contribution to total inequality (Podder, 1993). Nevertheless, a careful use of this approach can be useful to understand how different sources of income (in particular taxes and benefits) are distributed and contribute to total income inequality.
} 
The redistributive effect (RE) of taxes and benefits can be measured as the difference between the Gini coefficients of income before $\left(\mathrm{G}_{\mathrm{W}}\right)$ and after taxes and/or benefits $\left(\mathrm{G}_{\mathrm{X}}\right)$ :

$R E=G_{\mathrm{W}}-G_{\mathrm{X}}$

where $X$ is post-tax-benefit income $X=W+B-T, T$ denotes taxes and $B$ benefits.

\subsection{Efficiency and effectiveness of transfers at reducing poverty}

Certain types of benefits are designed to target low-income groups and reduce poverty. Beckerman (1979) proposes a set of indices to measure the degree of targeting and the poverty reduction efficiency of social benefits. These measures are illustrated in Figure 2 as follows:

- Vertical Expenditure Efficiency (VEE): is the share of total benefit expenditure going to households who are poor before the transfer. It is equal to the area $(A+B) /(A+B+C)$.

- Poverty Reduction Efficiency (PRE): is the fraction of total expenditure allowing poor households to reduce their distance from the poverty line without "overshooting" it. PRE is defined as $(A) /(A+B+C)$.

- Spillover index (S): is a measure of the excess expenditure with respect to the amount strictly necessary to reach the poverty line, $(B) /(A+B)$. Combining, we can see that the VEE $(1-S)=$ PRE.

- These three efficiency measures are, however, not sufficient to evaluate how effective a transfer system is at reducing poverty: A transfer program can be very efficient in reaching the poor, but its amount can nevertheless be too low to produce a significant increase in the living standards of beneficiaries. The Poverty Gap Efficiency (PGE) measure fills this gap. It is defined as $A /(A+D)$.

\subsection{Income definitions and the role of pensions}

Redistribution and targeting efficiency measures involve a comparison of incomes before and after accounting for the redistributive elements. Clearly, the interpretation of relevant measures depends on the definition of the two income concepts that are being compared, i.e. the measures of 'base' and 'final' income.

Our 'final' income measure is disposable income (DI), i.e., market income plus private transfers minus taxes and (employee) contributions plus cash benefits. We use two different definitions of 'base' income. The first is defined as 'private' income (PI) and includes gross market income and private transfers. By comparing DI and PI, we can assess the overall redistributive effect of the tax-benefit system. The second 'base' income concept is 'private' income plus public pensions (PPI). By comparing DI and PPI, we can assess the redistributive effect or target efficiency of all tax-benefit instruments except pensions.

Separating the analysis of pensions from other types of transfers is useful as one can argue that pensions are not properly part of the redistributive system but should instead be considered as a private insurance or saving scheme, with redistribution taking the form of inter-temporal rather than inter-personal transfers. Yet, there is often a very 
significant mismatch between individual's social security contributions and their pension entitlement such that most public pension systems do in fact employ a significant degree of inter-personal redistribution (e.g. OECD, 2005b). This is especially the case in Brazil, where the social security system suffers a large deficit amounting to about 5\% of GDP in 2003. More than half of this is attributable to the civil servant pension scheme. ${ }^{12}$ We therefore provide a careful analysis of the redistributive impact of pensions as well.

All our results relate to the income position of individuals. However, following common practice, we assume that incomes are shared within household so that all household members enjoy the same living standards. We also account for economies of scale within the household such that more resources are required per person in smaller households than in larger ones. The precise equivalence scale used for comparing incomes across different households is the so-called 'modified' OECD scale. ${ }^{13}$

Poverty and targeting efficiency estimates are calculated using four different poverty cut-offs. Two are set at the national level as $60 \%$ and $30 \%$ of the national median equivalent disposable income. The other two are determined separately for each of the five geographical regions in Brazil using the same proportions of median equivalent incomes.

\section{RESULTS}

\subsection{Overall Redistribution}

The results produced by BRAHMS clearly reflect the high degree of income inequality and the relatively small equalising effects the tax-benefit system in Brazil. Table 1 shows the various income components expressed as proportions of disposable income for different income groups. Private income sources account for $85 \%$ of disposable income on average. While individuals in the top decile receive $44 \%$ of all private incomes in Brazil, the share of the bottom decile is very low at only $1 \%$.

Cash transfers from the government represent almost one quarter of household disposable income. However, it is striking that despite a relatively young population and high levels of income inequality and poverty, almost $94 \%$ of benefits are accounted for by pensions or pension supplements. Moreover, the distributional pattern of pensions is quite similar to that of private incomes - more than 60 percent of pensions are concentrated in the top quintile. The profiles for earnings-related and means-tested benefits show an inverted U-shape distribution, with the largest shares of benefit expenditure going to middle-income groups. The Bolsa escola benefit is the only social benefit clearly targeted at lower income households.

Although the income tax is usually at the centre of the tax policy debate in Brazil, it is apparent from Table 1 that social contributions represent a greater influence on household incomes. In addition, contributions are important for almost all income

\footnotetext{
${ }^{12}$ In a recent study, Sanches (2005) analyses by how much contributions would have to be raised (or benefits reduced) in order to reach intergenerational equilibrium for the civil servants regimes.

${ }^{13}$ This scale gives a weight of 1 to the first adult, 0.5 to further adults and 0.3 to children aged under 14 . Following Buhmann et al (1988), we have performed sensitivity analyses using an equivalence scale, $e_{h}=$ $n^{s}$, with several different values of $s(0,0.5,0.75$ and 1$)$. The sensitivity analysis shows that although the estimates are of course affected, the main trends and conclusions in this paper are robust. These results are available from the authors.
} 
groups, while personal income taxes are concentrated at the top of the income distribution. More than $97 \%$ of the income tax revenue comes from the top decile.

Adding up the influence of all tax-benefit measures confirms that the tax-benefit system only has a relatively minor effect on the income shares of each decile group. The shares shown for private incomes, gross incomes and disposable incomes are quite similar (shown in bold typeface in Table 1). The distribution of gross income, which includes private incomes as well as all cash benefits, shows a very similar pattern to the distribution of private incomes only. In particular, the share of top and bottom deciles remains practically the same after adding cash transfers. Taxes and social contributions reduce the income share of the richest decile group to $42 \%$ but the share of the poorest $10 \%$ remains unchanged at $1 \%$.

Table 2 shows a decomposition of the Gini inequality measure along the lines of equation (3). The concentration coefficient of private income and pensions (as well as the annual bonus for pensioners) are larger than the Gini coefficient of disposable income (shown at the bottom of the table). This indicates that these income components are particularly important driving factors of income inequality in Brazil. Unemployment benefits and salary bonus are more equally distributed across income groups and have, in any case, less of an influence on overall inequality due to their low shares of disposable income. The concentration coefficients of Family benefit and Bolsa Escola are negative, indicating that these benefits tend to be targeted towards low-income groups. The positive concentration coefficients shown for the two negative income components (personal income taxes and social contributions) confirm that tax burdens increase at higher income levels, especially in the case of income taxes. Despite the progressivity, their relatively small size as a fraction of disposable incomes means that their equalising power is limited.

The results in Tables 1 and 2 only provide a partial picture of the redistributive power of the tax-benefit system, however. This is because they show the incidence of the various policy instruments using an income ranking based on disposable income measured net of all taxes and benefits. This approach ignores the fact that taxes and benefits also alter the income ranking itself.

The problem is most obvious in the case of pensions. Since pensions are relatively generous, Table 1 shows that a very large part of pension expenditure goes to higherincome groups. The results in Table 2 also reflect this. ${ }^{14}$ However, most pensioners live in households with low or zero market income. As a result, they are members of higherincome groups because they receive pensions. Without them they would tend to have extremely low incomes. Therefore, inequality and poverty could be substantially higher if pensions were excluded. This is captured by comparing Gini coefficients before and after pensions along the lines of equation (4). Measured in such a way, the redistributive effect of pensions tends to be significantly positive.

This is shown in Table 3 which presents Lorenz curves and Gini coefficients for different income concepts: private incomes (PI), private incomes plus pensions (PPI), gross incomes (PPI plus non-pension transfers) and disposable income (DI = gross income minus taxes and contributions). Pensions, taxes and other benefits

\footnotetext{
${ }^{14}$ A similar approach using concentration coefficients has been used by Hoffmann (2003) to show that pensions contribute to increase overall inequality in Brazil.
} 
unambiguously reduce income inequality by moving the Lorenz curve in the upward direction and reducing the Gini coefficient and the top/bottom quintile ratio.

\subsection{Targeting and poverty reduction}

Table 4 compares the poverty-reducing properties of means-tested benefits using the measures discussed in Section 4.2 and two different poverty thresholds. Using the $60 \%$ poverty cut-off, 35\% of the expenditure on these benefits is targeted to the poor, with only $13 \%$ of this representing spill-over (i.e. increasing incomes of poor individuals to levels above the poverty line). In total, means-tested benefits reduce the poverty gap by $10 \%$.

By type of benefit, Bolsa Escola is significantly more targeted to the poor than the earnings-related contributory benefits (unemployment benefit, salary bonus and family benefit). More than two thirds of Bolsa Escola spending reaches poor families and the spill-over effect is negligible. While family benefits are also very targeted towards the poor, a comparison with the second panel of Table 4 shows that they do not reach the very poorest families. Since a large share of family benefits go to families close to the $60 \%$ poverty line, almost two thirds of the funds directed to the poor "spill over" the poverty threshold.

As unemployment benefits account for half the overall expenditure on means-tested and earnings-related benefits, it has the largest impact on the poverty gap when using the higher (60\%) poverty line. However, the second panel of Table 4 shows that unemployment benefits are much less effective at reaching the poorest families whose income is below $30 \%$ of the national median (which corresponds to an income level of about $40 \%$ of the national minimum wage for a single person household). Despite being the smallest programme, the highly targeted Bolsa Escola reduces the poverty gap by a similar amount as unemployment benefits when using the higher poverty threshold and is considerably more effective at improving the income situation of the poorest population.

\subsection{Regional Analysis}

The geographical regions in Brazil are very heterogeneous and income patterns vary significantly between them. BRAHMS exploits the regional information available in the PNAD data and therefore allows us to analyse the redistributive effects of the taxbenefit system for the populations in each of the main geographical areas.

Table 5 shows that the decomposition by income component is quite different. In the North and Centre-west regions, cash benefits (particularly pensions) represent much smaller shares of disposable income than in the other three regions or the country as a whole. However, whereas the concentration coefficient of pensions is lower than the national average in the North, it is substantially higher in the Centre-west.

The share of pensions and other benefits of disposable income is highest in the Northeaster region (where 'private' income inequality is highest) and lowest in the North (which also has the lowest 'private' income inequality). Relative to disposable incomes, taxes and contributions are largest in the South-east.

In general the concentration coefficients of most benefits (including Bolsa Escola, income tax and contributions) are higher than the national average. The Southeastern 
and Southern regions are relatively closer to the national average although the concentration indices of taxes, benefits and initial income tend to be slightly lower.

Similarly to what was observed at the national level, Table 6 shows that pensions, taxes and other benefits unambiguously reduce the Gini coefficient. The overall redistributive effect of taxes and benefits is most substantial where benefits represent the largest share of disposable incomes (in the South, Northeast and Southeast). In all regions, pensions contribute most to reducing the Gini coefficient.. Income taxes and social contributions reduce inequality by more than non-pension benefits and have a larger equalising effect in the richer regions (South and Southeast).

There is also substantial regional variation in terms of benefit targeting. However, median income levels, and poverty thresholds defined in relation to them, are very different across regions (top row of second panel in Table 7). The results are therefore very sensitive the definition of the poverty line. Table 7 shows that using a poverty line equal to $60 \%$ of the national median, the proportion of the expenditure targeted to the poor is greater in the North and Northeast regions and smaller in the South and Southeast. The Poverty Gap Efficiency measure tends to be lower in the northern regions and higher in the southern ones. Similar regional patterns are observed using a poverty line equal to $30 \%$ of the national median (not shown).

However, the poverty-reducing effects of cash benefits are much more similar across regions when using region-specific poverty lines set as percentages of regional median incomes. Regional poverty lines are, of course, lower in the low-income regions. Relative to these regional poverty cut-offs, benefit payments appear to reduce the poverty gaps to a similar extent in all regions (PGE measure). However, at the same time, the results illustrate that little regional differentiation is built into the benefit system. When taking into account that average incomes differ across regions, lowincome regions see a smaller percentage of benefit expenditures go to the poor households than high-income regions (VEE measure).

\subsection{International Perspective}

How do the results observed in Brazil compare with those in other countries? In this section we contrast our estimates for Brazil with those observed in countries of the European Union, where analyses of the redistributive effects of tax-benefit systems have a longer tradition.

Table 8 shows the concentration coefficient and the average share of the components of disposable income in Brazil and in the EU-15 countries. The differences are striking. The concentration coefficient and the share of pensions as a proportion of disposable income are much higher in Brazil than the EU. In fact, the concentration coefficient of pensions is negative in the Nordic countries, the UK, Ireland, Belgium and the Netherlands. The concentration indices of Brazilian non-pension benefits are comparable to those of France and the UK. However, these countries spend much more on these benefits (about 15\% as a proportion of disposable income compared to $1.5 \%$ in Brazil). No EU country exhibits income taxes and contributions as concentrated on the better off as Brazil. Yet, even in the European countries with the lowest proportion of such taxes (Ireland and Spain), income taxes and contributions represent a share of household incomes that is about three times as large as in Brazil. 
Given these differences, it is not surprising that the equalising effect of tax-benefit policies other than pensions is much smaller in Brazil than in the EU (Table 9). In the EU country with the lowest degree of redistribution overall (Italy), non-pension benefits and taxes reduce the Gini by (in absolute terms) about 2.5 times as much as in Brazil.

Although Brazilian non-pension benefits compare well in terms of targeting, they are substantially less effective in reducing the poverty gap (Table 10). Non-pension benefits in Brazil reduce the poverty gap by $10 \%$ while, in almost all EU countries, the size of the poverty gap is reduced by more than $60 \%$.

\section{Conclusions}

This study offers additional evidence to the conclusion reached by Chu et al. (2000) that the redistributive effects of tax-benefit systems in developing (and transition) countries are much more limited than those observed in developed countries. In the case of Brazil, however, the problem cannot be attributed simply to low tax burdens. Instead, social spending bears little relation to need. This is particularly true in the case of pensions, which account for $85 \%$ of total benefit expenditure but are too concentrated on a relatively small group of beneficiaries to have a significant impact on poverty.

We have therefore performed a detailed analysis of the targeting efficiency of other, currently much smaller, cash benefits. The results show that a number of these benefits are quite successful at targeting the poor. Yet, while assistance programs like the Bolsa Escola are well-targeted on the most vulnerable population, the budget devoted to these programs is still a minuscule share of total social spending and their impact in terms of poverty reduction is therefore limited.

These results suggest that there is indeed significant scope to improve the povertyreducing performance of the transfer system, by spreading benefits more equally. Given the small share of well-targeted benefits in the current system, even relatively small increases in the funds devoted to successful programmes like the Bolsa Escola could have a very favourable impact on the income situation of the poor. Our results also suggest that more regionally differentiated transfers could be a more cost effective way of reducing poverty. This latter aspect is particularly relevant in Brazil which is characterised by considerable regional disparities.

Similarly, researchers and policy-makers in Brazil have frequently argued that the tax side of the budget should play a more significant redistributive role. However, the predominance of indirect taxes and the interaction of a progressive personal income tax interact with the highly unequal income distribution render the tax system a poor redistributive tool. Furthermore, there are indications that the most affluent groups have tended to benefit most from tax concessions and, more generally, tax avoidance opportunities and difficulties in enforcing tax compliance.

In a society as unequal as the Brazilian, political economy considerations should be central to any proposal intended to improve the way taxes and benefits are distributed amongst its population. Our view is that the tax-benefit system should be as simple and transparent as possible, with the expenditure side of the budget as the fundamental redistributive instrument - primarily through the provision of basic services and welltargeted direct transfers to households. We would argue that this would be a key condition to convince and empower voters to push for more effective redistributive policies. 
Careful modelling of policy alternatives can contribute to this process. This paper has addressed a number of potential technical modelling developments that are desirable and as such create an agenda for future work.

In order to aid future policy reform analysis, it would be desirable to extend the number of policy instruments simulated in the model, particularly indirect taxes and non-cash transfers such as health and education. Recent and on-going work in OECD countries indicates that model extensions in these directions would in fact be feasible in Brazil. This would allow analysts to evaluate the cost and redistributive impact of comprehensive policy packages. 


\section{REFERENCES}

Atkinson, A.B. and F. Bourguignon (1990) "Tax-benefit models for developing countries: lessons from developed countries", Ecole Normale Superieure, DELTA Working Paper 90-15, Paris.

Buhmann, B., L.Rainwater, G. Schmaus, and T. Smeeding (1988) "Equivalence scales, well-being, inequality and poverty: Sensitivity estimates across ten countries using the Luxembourg Income Study (LIS) database”, The Review of Income and Wealth, 34, 115-142.

Chu, K., H. Davoodi, and S. Gupta, (2000) "Income distribution, tax, and government social spending policies in developing countries”, Working Paper No. 214, World Institute for Development Economics Research, The United Nations University, Helsinki.

Creedy, J. (1997) "Evaluating income tax changes and the choice of income measure", Department of Economics, University of Melbourne, Research Paper No. 577.

Förster, M. and M. Mira d'Ercole (2005) "Income distribution and poverty in OECD countries in the second half of the 1990s", OECD Social, Employment and Migration Working Papers, No. 22.

Hoffmann, R. (2003) "Inequality in Brazil: the contribution of pensions", Revista Brasileira de Economia, Vol. 57, No.4.

Immervoll, H., C. O’Donoghue, and H. Sutherland (1999) “An introduction to EUROMOD”, EUROMOD Working Paper EM0/99, ISER, University of Essex, Colchester.

Immervoll, H., H. Levy, J. R. Nogueira, C. O’Donoghue, and R. B. Siqueira (2003) "Simulating Brazil's tax-benefit system using BRAHMS, the Brazilian household micro-simulation model”, paper presented at the WIDER International Conference on Inequality, Poverty and Human Well Being.

Immervoll, H., H. Levy, C. Lietz, D. Mantovani, C. O'Donoghue, H. Sutherland, and G. Verbist (2006), "Household Incomes and Redistribution in the European Union; Quantifying the Equalizing Properties of Taxes and Benefits", in D. B. Papadimitriou (ed.) The Distributional Effects of Government Spending and Taxation, Basingstone: Palgrave-MacMillan.

Ministry of the Economy (2005) Orçamento Social do Governo Federal 2001-2004, Secretaria de Política Econômica, Ministério da Fazenda, Brasília; available electronically at http://www.fazenda.gov.br/portugues/releases/2005/OS200429abr.pdf.

OECD (2005a) Economic Survey of Brazil 2005, Economics Department, Organisation for Economic Co-operation and Development, Paris.

OECD (2005b) Pensions at a Glance, Organisation for Economic Co-operation and Development, Paris.

Palme, M., (1996) "Income distribution effects of the Swedish 1991 tax reform: an analysis of a microsimulation using generalised Kakwani decomposition", Journal of Policy Modelling, vol. 18, No. 4. 
Podder, N. (1993) "The disaggregation of the Gini coefficient by factor components and its application to Australia”, Review of Income and Wealth, vol.39, No. 1.

Sanches, F. (2005) "Balanço intergeracional: desequilíbrio fiscal e reforma da previdência no Brasil”, X Prêmio Tesouro Nacional, Brasília: ESAF.

Siqueira, R., J. R. Nogueira, and H. Levy (2003) "Política tributária e política social no Brasil: impacto sobre a distribuição de renda entre os domicílios”, in D. W. Benecke and R. Nascimento (org.) Política Social Preventiva para o Brasil: Desafio para o Brasil. Rio de Janeiro: Fundação Konrad Adenauer.

Siqueira, R. B., J. R. Nogueira, and E. S. Souza (2000) “Os impostos sobre consumo no Brasil são regressivos?”, Economia Aplicada, vol. 4, No. 4.

Sutherland H. (2001), "EUROMOD: an integrated European benefit-tax model, final report”, EUROMOD Working Paper EM9/01, ISER, University of Essex, Colchester.

Table 1. Proportion and distribution of income by deciles in Brazil (in \%)

\begin{tabular}{|c|c|c|c|c|c|c|c|c|c|c|c|}
\hline & $\begin{array}{c}\text { Share of } \\
\text { disposable }\end{array}$ & \multicolumn{10}{|c|}{ Distribution by decile } \\
\hline & & 1 & 2 & 3 & 4 & 5 & 6 & 7 & 8 & 9 & 10 \\
\hline Private Income & 84.9 & 1.0 & 2.1 & 2.9 & 3.9 & 4.7 & 5.9 & 8.1 & 10.8 & 16.2 & 44.3 \\
\hline Benefits & 22.5 & 0.8 & 2.1 & 3.4 & 4.2 & 6.1 & 7.5 & 7.6 & 10.7 & 16.5 & 41.2 \\
\hline Pension & 19.4 & 0.3 & 1.6 & 2.8 & 3.6 & 5.7 & 7.2 & 7.3 & 10.7 & 17.1 & 43.7 \\
\hline Annual Bonus & 1.6 & 0.3 & 1.6 & 2.8 & 3.6 & 5.7 & 7.2 & 7.3 & 10.7 & 17.1 & 43.7 \\
\hline Unemploy Ben & 0.7 & 5.5 & 5.2 & 8.2 & 10.7 & 11.8 & 12.2 & 14.3 & 14.0 & 11.2 & 6.8 \\
\hline Salary Bonus & 0.2 & 3.2 & 7.4 & 11.0 & 13.5 & 13.3 & 14.4 & 15.1 & 12.0 & 7.5 & 2.7 \\
\hline Family Benefit & 0.3 & 4.6 & 15.3 & 16.5 & 18.8 & 12.8 & 12.1 & 10.0 & 6.0 & 3.1 & 0.8 \\
\hline Bolsa Escola & 0.2 & 24.7 & 23.2 & 17.7 & 13.5 & 9.5 & 5.8 & 3.2 & 1.3 & 0.8 & 0.3 \\
\hline Gross Income & 107.4 & 1.0 & 2.1 & 3.0 & 4.0 & 5.0 & 6.2 & 8.0 & 10.8 & 16.3 & 43.7 \\
\hline Direct Taxes & 7.4 & 0.1 & 0.7 & 1.1 & 1.9 & 2.6 & 3.4 & 5.2 & 7.4 & 12.2 & 65.4 \\
\hline Social Contrib & 3.9 & 0.3 & 1.2 & 2.2 & 3.6 & 4.8 & 6.4 & 9.9 & 14.0 & 20.7 & 37.0 \\
\hline Income Tax & 3.5 & 0.0 & 0.0 & 0.0 & 0.0 & 0.0 & 0.0 & 0.0 & 0.1 & 2.8 & 97.1 \\
\hline Disp Income & 100.0 & 1.0 & 2.2 & 3.2 & 4.1 & 5.2 & 6.5 & 8.2 & 11.0 & 16.6 & 42.1 \\
\hline
\end{tabular}

Notes: Private Income: total annual income of all members of the household before the deduction of taxes or the addition of any state benefits. Gross Income: Private Income plus transfers. Disposable Income: Gross Income minus direct taxes and employee social security contributions.

Source: BRAHMS/PNAD 2003 
Table 2. Concentration coefficient and average share of components of disposable income in Brazil

\begin{tabular}{|c|c|c|}
\hline & $\begin{array}{c}\text { Concentration Index } \\
\mathrm{C}_{\mathbf{k}} \\
\end{array}$ & $\begin{array}{l}\text { Share of disposable income } \\
\qquad \mu_{\mathrm{k}} / \mu_{\mathrm{x}}\end{array}$ \\
\hline \multirow[t]{2}{*}{ Private Income } & 0.5586 & $84.9 \%$ \\
\hline & $(0.0021)$ & $(0.2 \%)$ \\
\hline \multirow[t]{2}{*}{ Benefits } & 0.5263 & $22.5 \%$ \\
\hline & $(0.0031)$ & $(0.2 \%)$ \\
\hline \multirow[t]{2}{*}{ Pension } & 0.5658 & $19.4 \%$ \\
\hline & $(0.0040)$ & $(0.2 \%)$ \\
\hline \multirow[t]{2}{*}{ Annual Bonus } & 0.5658 & $1.6 \%$ \\
\hline & $(0.0034)$ & $(0.0 \%)$ \\
\hline \multirow[t]{2}{*}{ Unemployment Benefit } & 0.0966 & $0.7 \%$ \\
\hline & $(0.0061)$ & $(0.0 \%)$ \\
\hline \multirow[t]{2}{*}{ Salary Bonus } & 0.0079 & $0.2 \%$ \\
\hline & $(0.0039)$ & $(0.0 \%)$ \\
\hline \multirow[t]{2}{*}{ Family Benefit } & -0.1982 & $0.3 \%$ \\
\hline & $(0.0045)$ & $(0.0 \%)$ \\
\hline \multirow[t]{2}{*}{ Bolsa escola } & -0.4953 & $0.2 \%$ \\
\hline & $(0.0038)$ & $(0.0 \%)$ \\
\hline \multirow[t]{2}{*}{ Income tax } & 0.9546 & $-3.5 \%$ \\
\hline & $(0.0009)$ & $(0.1 \%)$ \\
\hline \multirow[t]{2}{*}{ Social Contributions } & 0.5568 & $-3.9 \%$ \\
\hline & $(0.0027)$ & $(0.0 \%)$ \\
\hline \multirow[t]{2}{*}{ Disposable Income } & 0.5376 & $100.0 \%$ \\
\hline & $(0.0018)$ & $(0.0 \%)$ \\
\hline
\end{tabular}

Notes: Bootstrapped standard error in parenthesis.

Source: BRAHMS/PNAD 2003 
Table 3. Lorenz curves, quintile ratios and Gini coefficients for different income definitions in Brazil

\begin{tabular}{|c|c|c|c|c|}
\hline & $\begin{array}{c}\text { Private Income } \\
\text { (PI) } \\
\end{array}$ & $\begin{array}{c}\text { Private Income } \\
\text { plus pensions } \\
\text { (PPI) } \\
\end{array}$ & Gross Income & $\begin{array}{c}\text { Disposable Income } \\
\text { (DI) } \\
\end{array}$ \\
\hline \multicolumn{5}{|l|}{ Lorenz Curve } \\
\hline 1 & $\begin{array}{r}0.06 \\
(0.00)\end{array}$ & $\begin{array}{r}0.84 * \\
(0.01)\end{array}$ & $\begin{array}{r}0.95 * \\
(0.01)\end{array}$ & $\begin{array}{r}1.02 * \\
(0.01)\end{array}$ \\
\hline 2 & $\begin{array}{r}1.34 \\
(0.03)\end{array}$ & $\begin{array}{r}2.85 * \\
(0.00)\end{array}$ & $\begin{array}{r}3.08 * \\
(0.02)\end{array}$ & $\begin{array}{r}3.26 * \\
(0.00)\end{array}$ \\
\hline 3 & $\begin{array}{r}3.68 \\
(0.06)\end{array}$ & $\begin{array}{r}5.75 * \\
(0.00)\end{array}$ & $\begin{array}{r}6.10 * \\
(0.04)\end{array}$ & $\begin{array}{r}6.42 * \\
(0.04)\end{array}$ \\
\hline 4 & $\begin{array}{r}6.98 \\
(0.07)\end{array}$ & $\begin{array}{r}9.60 * \\
(0.00)\end{array}$ & $\begin{array}{l}10.07 * \\
(0.05)\end{array}$ & $\begin{array}{l}10.55 * \\
(0.08)\end{array}$ \\
\hline 5 & $\begin{array}{l}11.47 \\
(0.08)\end{array}$ & $\begin{array}{l}14.51 * \\
(0.01)\end{array}$ & $\begin{array}{l}15.07 * \\
(0.06)\end{array}$ & $\begin{array}{l}15.73 * \\
(0.13)\end{array}$ \\
\hline 6 & $\begin{array}{l}17.38 \\
(0.10)\end{array}$ & $\begin{array}{l}20.69 * \\
(0.01)\end{array}$ & $\begin{array}{l}21.31 * \\
(0.04)\end{array}$ & $\begin{array}{l}22.19 * \\
(0.19)\end{array}$ \\
\hline 7 & $\begin{array}{l}25.21 \\
(0.14)\end{array}$ & $\begin{array}{l}28.63 * \\
(0.01)\end{array}$ & $\begin{array}{l}29.30 * \\
(0.01)\end{array}$ & $\begin{array}{l}30.39 * \\
(0.27)\end{array}$ \\
\hline 8 & $\begin{array}{l}36.01 \\
(0.16)\end{array}$ & $\begin{array}{l}39.41 * \\
(0.09)\end{array}$ & $\begin{array}{l}40.07 * \\
(0.06)\end{array}$ & $\begin{array}{l}41.41 * \\
(0.32)\end{array}$ \\
\hline 9 & $\begin{array}{l}52.64 \\
(0.12)\end{array}$ & $\begin{array}{l}55.79 * \\
(0.16)\end{array}$ & $\begin{array}{l}56.32 * \\
(0.11)\end{array}$ & $\begin{array}{l}57.96 * \\
(0.33)\end{array}$ \\
\hline 10 & $\begin{array}{r}100.00 \\
(0.00) \\
\end{array}$ & $\begin{array}{r}100.00 \\
(0.00) \\
\end{array}$ & $\begin{array}{r}100.00 \\
(0.00) \\
\end{array}$ & $\begin{array}{r}100.00 \\
(0.00) \\
\end{array}$ \\
\hline $\begin{array}{l}\text { Top/bottom } \\
\text { quintile ratio }\end{array}$ & $\begin{array}{l}47.69 \\
(1.13) \\
\end{array}$ & $\begin{array}{l}21.24 * \\
(0.05)\end{array}$ & $\begin{array}{l}19.44 * \\
(0.12)\end{array}$ & $\begin{array}{l}17.99 * \\
(0.12)\end{array}$ \\
\hline $\begin{array}{l}\text { Gini } \\
\text { coefficient }\end{array}$ & $\begin{array}{r}0.6092 \\
(0.0017)\end{array}$ & $\begin{array}{c}0.5609 * \\
(0.0019)\end{array}$ & $\begin{array}{c}0.5523 * \\
(0.0018)\end{array}$ & $\begin{array}{c}0.5376 * \\
(0.0016)\end{array}$ \\
\hline
\end{tabular}

Notes: Bootstrapped standard error in parenthesis. * Indicates that the difference between this estimate and the one corresponding to the previous income definition is significant at the $5 \%$ level.

Source: BRAHMS/PNAD 2003 
Table 4. Poverty efficiency of means-tested and earnings-related benefits in Brazil

\begin{tabular}{|c|c|c|c|c|}
\hline & $\begin{array}{c}\text { Vertical } \\
\text { Expenditure } \\
\text { Efficiency } \\
\text { (VEE) }\end{array}$ & $\begin{array}{c}\text { Poverty Reduction } \\
\text { Efficiency } \\
\text { (PRE) }\end{array}$ & $\begin{array}{l}\text { Spillover } \\
\text { (S) }\end{array}$ & $\begin{array}{l}\text { Poverty Gap } \\
\text { Efficiency } \\
\text { (PGE) }\end{array}$ \\
\hline \multicolumn{5}{|c|}{ Poverty line: $60 \%$ of national median disposable income } \\
\hline \multirow[t]{2}{*}{ Non-pension Benefits } & 0.351 & 0.305 & 0.130 & 0.099 \\
\hline & $(0.003)$ & $(0.003)$ & $(0.001)$ & $(0.000)$ \\
\hline \multirow[t]{2}{*}{ Unempl. Benefit } & 0.287 & 0.231 & 0.195 & 0.036 \\
\hline & $(0.005)$ & $(0.005)$ & $(0.003)$ & $(0.001)$ \\
\hline \multirow[t]{2}{*}{ Salary Bonus } & 0.214 & 0.204 & 0.046 & 0.011 \\
\hline & $(0.001)$ & $(0.000)$ & $(0.003)$ & $(0.000)$ \\
\hline \multirow[t]{2}{*}{ Family Benefit } & 0.380 & 0.355 & 0.067 & 0.023 \\
\hline & $(0.006)$ & $(0.008)$ & $(0.008)$ & $(0.001)$ \\
\hline \multirow[t]{2}{*}{ Bolsa escola } & 0.674 & 0.659 & 0.022 & 0.032 \\
\hline & $(0.008)$ & $(0.008)$ & $(0.001)$ & $(0.000)$ \\
\hline \multicolumn{5}{|c|}{ Poverty line: $30 \%$ of national median disposable income } \\
\hline \multirow[t]{2}{*}{ Non-pension Benefits } & 0.125 & 0.096 & 0.231 & 0.159 \\
\hline & $(0.001)$ & $(0.002)$ & $(0.009)$ & $(0.001)$ \\
\hline \multirow[t]{2}{*}{ Unempl. Benefit } & 0.115 & 0.084 & 0.268 & 0.067 \\
\hline & $(0.005)$ & $(0.004)$ & $(0.006)$ & $(0.002)$ \\
\hline \multirow[t]{2}{*}{ Salary Bonus } & 0.042 & 0.039 & 0.063 & 0.011 \\
\hline & $(0.001)$ & $(0.001)$ & $(0.000)$ & $(0.000)$ \\
\hline \multirow[t]{2}{*}{ Family Benefit } & 0.086 & 0.064 & 0.247 & 0.021 \\
\hline & $(0.001)$ & $(0.001)$ & $(0.006)$ & $(0.000)$ \\
\hline \multirow[t]{2}{*}{ Bolsa escola } & 0.304 & 0.276 & 0.092 & 0.068 \\
\hline & $(0.005)$ & $(0.004)$ & $(0.002)$ & $(0.002)$ \\
\hline
\end{tabular}

Notes: Bootstrapped standard error in parenthesis.

Source: BRAHMS/PNAD 2003

Table 5. Concentration coefficient and average share of components of disposable income in Brazilian regions

\begin{tabular}{|c|c|c|c|c|c|c|c|c|c|c|}
\hline & \multicolumn{2}{|c|}{ North } & \multicolumn{2}{|c|}{ North-East } & \multicolumn{2}{|c|}{ South-East } & \multicolumn{2}{|c|}{ South } & \multicolumn{2}{|c|}{ Centre-West } \\
\hline & $\mathrm{C}_{\mathrm{k}}$ & $\mu_{\mathrm{k}} / \mu_{\mathrm{x}}$ & $\mathrm{C}_{\mathrm{k}}$ & $\mu_{\mathrm{k}} / \mu_{\mathrm{x}}$ & $\mathrm{C}_{\mathrm{k}}$ & $\mu_{\mathrm{k}} / \mu_{\mathrm{x}}$ & $\mathrm{C}_{\mathrm{k}}$ & $\mu_{\mathrm{k}} / \mu_{\mathrm{x}}$ & $\mathrm{C}_{\mathrm{k}}$ & $\mu_{\mathrm{k}} / \mu_{\mathrm{x}}$ \\
\hline \multirow[t]{2}{*}{ Private Income } & 0.516 & $89.3 \%$ & 0.548 & $77.9 \%$ & 0.533 & $85.6 \%$ & 0.504 & $85.5 \%$ & 0.558 & $91.3 \%$ \\
\hline & $(0.006)$ & $-(0.5 \%)$ & $(0.004)$ & $-(0.4 \%)$ & $(0.003)$ & $-(0.3 \%)$ & $(0.005)$ & $-(0.5 \%)$ & $(0.006)$ & $-(0.5 \%)$ \\
\hline \multirow[t]{2}{*}{ Benefits } & 0.472 & $15.9 \%$ & 0.543 & $27.1 \%$ & 0.516 & $22.8 \%$ & 0.475 & $21.8 \%$ & 0.552 & $16.1 \%$ \\
\hline & $(0.013)$ & $-(0.5 \%)$ & $(0.007)$ & $-(0.4 \%)$ & $(0.005)$ & $-(0.3 \%)$ & $(0.008)$ & $-(0.3 \%)$ & $(0.012)$ & $-(0.4 \%)$ \\
\hline \multirow[t]{2}{*}{ Pension } & 0.53 & $13.1 \%$ & 0.589 & $22.9 \%$ & 0.552 & $19.9 \%$ & 0.514 & $18.9 \%$ & 0.606 & $13.7 \%$ \\
\hline & $(0.013)$ & $-(0.4 \%)$ & $(0.006)$ & $-(0.3 \%)$ & $(0.006)$ & $-(0.3 \%)$ & $(0.008)$ & $-(0.4 \%)$ & $(0.013)$ & $-(0.5 \%)$ \\
\hline \multirow[t]{2}{*}{ Annual Bonus } & 0.53 & $1.1 \%$ & 0.589 & $1.9 \%$ & 0.552 & $1.7 \%$ & 0.514 & $1.6 \%$ & 0.606 & $1.1 \%$ \\
\hline & $(0.012)$ & $(0.0 \%)$ & $(0.006)$ & $(0.0 \%)$ & $(0.005)$ & $(0.0 \%)$ & $(0.008)$ & $(0.0 \%)$ & $(0.016)$ & $(0.0 \%)$ \\
\hline \multirow[t]{2}{*}{ Unemp. Ben. } & 0.139 & $0.7 \%$ & 0.23 & $0.7 \%$ & -0.015 & $0.6 \%$ & 0 & $0.7 \%$ & 0.073 & $0.7 \%$ \\
\hline & $(0.024)$ & $(0.0 \%)$ & $(0.014)$ & $(0.0 \%)$ & $(0.012)$ & $(0.0 \%)$ & $(0.015)$ & $(0.0 \%)$ & $(0.024)$ & $(0.0 \%)$ \\
\hline \multirow[t]{2}{*}{ Salary Bonus } & 0.12 & $0.3 \%$ & 0.257 & $0.4 \%$ & -0.123 & $0.2 \%$ & -0.072 & $0.2 \%$ & -0.055 & $0.2 \%$ \\
\hline & $(0.014)$ & $(0.0 \%)$ & $(0.007)$ & $(0.0 \%)$ & $(0.008)$ & $(0.0 \%)$ & $(0.011)$ & $(0.0 \%)$ & $(0.013)$ & $(0.0 \%)$ \\
\hline \multirow[t]{2}{*}{ Family Benefit } & -0.154 & $0.4 \%$ & -0.013 & $0.4 \%$ & -0.337 & $0.2 \%$ & -0.29 & $0.3 \%$ & -0.246 & $0.2 \%$ \\
\hline & $(0.017)$ & $(0.0 \%)$ & $(0.010)$ & $(0.0 \%)$ & $(0.008)$ & $(0.0 \%)$ & $(0.010)$ & $(0.0 \%)$ & $(0.016)$ & $(0.0 \%)$ \\
\hline \multirow[t]{2}{*}{ Bolsa escola } & -0.322 & $0.3 \%$ & -0.323 & $0.6 \%$ & -0.549 & $0.1 \%$ & -0.569 & $0.1 \%$ & -0.438 & $0.2 \%$ \\
\hline & $(0.015)$ & $(0.0 \%)$ & $(0.007)$ & $(0.0 \%)$ & $(0.008)$ & $(0.0 \%)$ & $(0.011)$ & $(0.0 \%)$ & $(0.015)$ & $(0.0 \%)$ \\
\hline \multirow[t]{2}{*}{ Income tax } & 0.97 & $-1.9 \%$ & 0.979 & $-2.1 \%$ & 0.94 & $-4.1 \%$ & 0.946 & $-3.3 \%$ & 0.945 & $-3.6 \%$ \\
\hline & $(0.002)$ & $-(0.1 \%)$ & $(0.001)$ & $-(0.1 \%)$ & $(0.001)$ & $-(0.1 \%)$ & $(0.002)$ & $-(0.1 \%)$ & $(0.003)$ & $-(0.2 \%)$ \\
\hline \multirow[t]{2}{*}{ Social Contrib. } & 0.575 & $-3.3 \%$ & 0.659 & $-2.9 \%$ & 0.481 & $-4.3 \%$ & 0.451 & $-4.0 \%$ & 0.56 & $-3.8 \%$ \\
\hline & $(0.007)$ & $-(0.1 \%)$ & $(0.005)$ & $(0.0 \%)$ & $(0.004)$ & $(0.0 \%)$ & $(0.005)$ & $(0.0 \%)$ & $(0.007)$ & $-(0.1 \%)$ \\
\hline Disposable & 0.498 & $100.0 \%$ & 0.534 & $100.0 \%$ & 0.515 & $100.0 \%$ & 0.485 & $100.0 \%$ & 0.543 & $100.0 \%$ \\
\hline Income & $(0.004)$ & $(0.0 \%)$ & $(0.003)$ & $(0.0 \%)$ & $(0.003)$ & $(0.0 \%)$ & $(0.003)$ & $(0.0 \%)$ & $(0.004)$ & $(0.0 \%)$ \\
\hline
\end{tabular}

Notes: Bootstrapped standard error in parenthesis.

Source: BRAHMS/PNAD 2003 
Table 6. Gini coefficients for different income definitions in Brazilian regions

\begin{tabular}{lcccc}
\hline & Private Income & $\begin{array}{c}\text { Private Income } \\
\text { plus pensions } \\
(\mathbf{P P I})\end{array}$ & $\begin{array}{c}\text { Gross Income } \\
\text { (PI) }\end{array}$ & $\begin{array}{c}\text { Disposable Income } \\
\text { (DI) }\end{array}$ \\
\hline Brazil & 0.6092 & $(0.0019)$ & $0.5523 *$ & $0.5376^{*}$ \\
& $(0.0017)$ & $0.5185^{*}$ & $0.0018)$ & $(0.0016)$ \\
\hline North & 0.5520 & $(0.0047)$ & $(0.5094$ & 0.4981 \\
North-East & $(0.0051)$ & $0.5588^{*}$ & 0.5469 & $(0.0046)$ \\
& 0.6146 & $(0.0036)$ & $(0.0032)$ & $0.5341^{*}$ \\
South-East & $(0.0037)$ & $0.5377^{*}$ & 0.5300 & $(0.0033)$ \\
& 0.5889 & $(0.0025)$ & $(0.0027)$ & $0.5149 *$ \\
South & $(0.0033)$ & $0.5068 *$ & 0.4985 & $0.0027)$ \\
& 0.5586 & $(0.0040)$ & $(0.0038)$ & 0.4850 \\
Centre-West & $(0.0039)$ & $0.5657 *$ & 0.5577 & $(0.0034)$ \\
& 0.5892 & $(0.0047)$ & $(0.0044)$ & 0.5431 \\
& $(0.0046)$ & $0.0038)$
\end{tabular}

Notes: Bootstrapped standard error in parenthesis. * Indicates that the difference between this estimate and the one corresponding to the previous income definition is significant at the $5 \%$ level.

Source: BRAHMS/PNAD 2003

Table 7. Poverty efficiency of means-tested and earnings-related benefits in Brazilian regions

\begin{tabular}{|c|c|c|c|c|c|c|c|c|c|c|}
\hline & \multicolumn{2}{|c|}{ North } & \multicolumn{2}{|c|}{ Northeast } & \multicolumn{2}{|c|}{ Southeast } & \multicolumn{2}{|c|}{ South } & \multicolumn{2}{|c|}{ Centre-West } \\
\hline & VEE & PGE & $\begin{array}{l}\text { VEE } \\
\end{array}$ & PGE & VEE & PGE & VEE & PGE & VEE & PGE \\
\hline \multicolumn{11}{|c|}{ Poverty line: $60 \%$ of national median disposable income } \\
\hline \multirow[t]{2}{*}{ Non-pension benefits } & 0.402 & $9.2 \%$ & 0.567 & $8.1 \%$ & 0.275 & $12.2 \%$ & 0.224 & $13.9 \%$ & 0.303 & $10.9 \%$ \\
\hline & $(0.010)$ & $(0.0 \%)$ & $(0.002)$ & $(0.0 \%)$ & $(0.004)$ & $(0.0 \%)$ & $(\mathbf{0 . 0 1 5})$ & $(0.1 \%)$ & $(0.020)$ & $(\mathbf{1 . 0 \% )}$ \\
\hline \multirow[t]{2}{*}{ Unempl. Benefit } & 0.345 & $3.2 \%$ & 0.496 & $2.2 \%$ & 0.241 & $5.6 \%$ & 0.199 & $6.0 \%$ & 0.268 & $4.8 \%$ \\
\hline & $(0.039)$ & $(0.4 \%)$ & $(0.013)$ & $(0.2 \%)$ & $(0.002)$ & $(0.1 \%)$ & $(0.005)$ & $(0.3 \%)$ & $(0.007)$ & $(0.1 \%)$ \\
\hline \multirow[t]{2}{*}{ Salary Bonus } & 0.246 & $1.0 \%$ & 0.318 & $0.9 \%$ & 0.185 & $1.6 \%$ & 0.113 & $1.3 \%$ & 0.186 & $1.1 \%$ \\
\hline & $(0.005)$ & $(0.1 \%)$ & $(0.001)$ & $(0.0 \%)$ & $(0.020)$ & $(0.2 \%)$ & $(0.019)$ & $(0.2 \%)$ & $(0.026)$ & $(0.2 \%)$ \\
\hline \multirow[t]{2}{*}{ Family Benefit } & 0.453 & $2.4 \%$ & 0.582 & $1.6 \%$ & 0.330 & $3.1 \%$ & 0.233 & $3.5 \%$ & 0.328 & $2.5 \%$ \\
\hline & $(0.012)$ & $(0.1 \%)$ & $(0.001)$ & $(0.0 \%)$ & $(0.003)$ & $(0.1 \%)$ & $(0.009)$ & $(0.1 \%)$ & $(0.014)$ & $(0.2 \%)$ \\
\hline \multirow[t]{2}{*}{ Bolsa escola } & 0.609 & $2.9 \%$ & 0.794 & $3.6 \%$ & 0.558 & $2.3 \%$ & 0.513 & $3.8 \%$ & 0.533 & $3.0 \%$ \\
\hline & $(0.001)$ & $(0.1 \%)$ & $(0.000)$ & $(0.0 \%)$ & $(0.002)$ & $(0.0 \%)$ & $(0.030)$ & $(0.0 \%)$ & $(0.002)$ & $(0.0 \%)$ \\
\hline \multicolumn{11}{|c|}{ Poverty line: $60 \%$ of regional median disposable income } \\
\hline as $\%$ national pov. line & \multicolumn{2}{|c|}{$80 \%$} & \multicolumn{2}{|c|}{$59 \%$} & \multicolumn{2}{|c|}{$125 \%$} & \multicolumn{2}{|c|}{$134 \%$} & \multicolumn{2}{|c|}{$108 \%$} \\
\hline \multirow[t]{2}{*}{ Non-pension benefits } & 0.283 & $11.0 \%$ & 0.299 & $13.4 \%$ & 0.375 & $10.0 \%$ & 0.348 & $11.1 \%$ & 0.337 & $10.9 \%$ \\
\hline & $(0.003)$ & $(0.6 \%)$ & $(0.004)$ & $(0.1 \%)$ & $(0.001)$ & $(0.3 \%)$ & $(0.001)$ & $(0.2 \%)$ & $(0.002)$ & $(0.7 \%)$ \\
\hline \multirow[t]{2}{*}{ Unempl. Benefit } & 0.251 & $4.0 \%$ & 0.250 & $3.4 \%$ & 0.321 & $4.5 \%$ & 0.300 & $4.8 \%$ & 0.298 & $4.6 \%$ \\
\hline & $(0.009)$ & $(0.1 \%)$ & $(0.010)$ & $(0.0 \%)$ & $(0.014)$ & $(0.1 \%)$ & $(0.019)$ & $(0.3 \%)$ & $(0.017)$ & $(0.2 \%)$ \\
\hline \multirow[t]{2}{*}{ Salary Bonus } & 0.137 & $1.0 \%$ & 0.089 & $0.8 \%$ & 0.281 & $1.4 \%$ & 0.228 & $1.3 \%$ & 0.210 & $1.1 \%$ \\
\hline & $(0.002)$ & $(0.0 \%)$ & $(0.007)$ & $(0.1 \%)$ & $(0.005)$ & $(0.0 \%)$ & $(0.005)$ & $(0.0 \%)$ & $(0.016)$ & $(0.1 \%)$ \\
\hline \multirow[t]{2}{*}{ Family Benefit } & 0.302 & $2.7 \%$ & 0.268 & $2.3 \%$ & 0.477 & $2.7 \%$ & 0.409 & $3.0 \%$ & 0.375 & $2.7 \%$ \\
\hline & $(0.021)$ & $(0.4 \%)$ & $(0.009)$ & $(0.1 \%)$ & $(0.014)$ & $(0.1 \%)$ & $(0.017)$ & $(0.1 \%)$ & $(0.002)$ & $(0.1 \%)$ \\
\hline \multirow[t]{2}{*}{ Bolsa escola } & 0.460 & $3.8 \%$ & 0.506 & $7.6 \%$ & 0.684 & $1.7 \%$ & 0.673 & $2.4 \%$ & 0.567 & $2.8 \%$ \\
\hline & $(0.010)$ & $(0.2 \%)$ & $(0.012)$ & $(0.0 \%)$ & $(0.005)$ & $(0.0 \%)$ & $(0.002)$ & $(0.1 \%)$ & $(0.024)$ & $(0.0 \%)$ \\
\hline
\end{tabular}

Notes: Bootstrapped standard error in parenthesis.

Source: BRAHMS/PNAD 2003 
Table 8. Concentration coefficient and average share of components of disposable income in Brazil and EU-15 countries

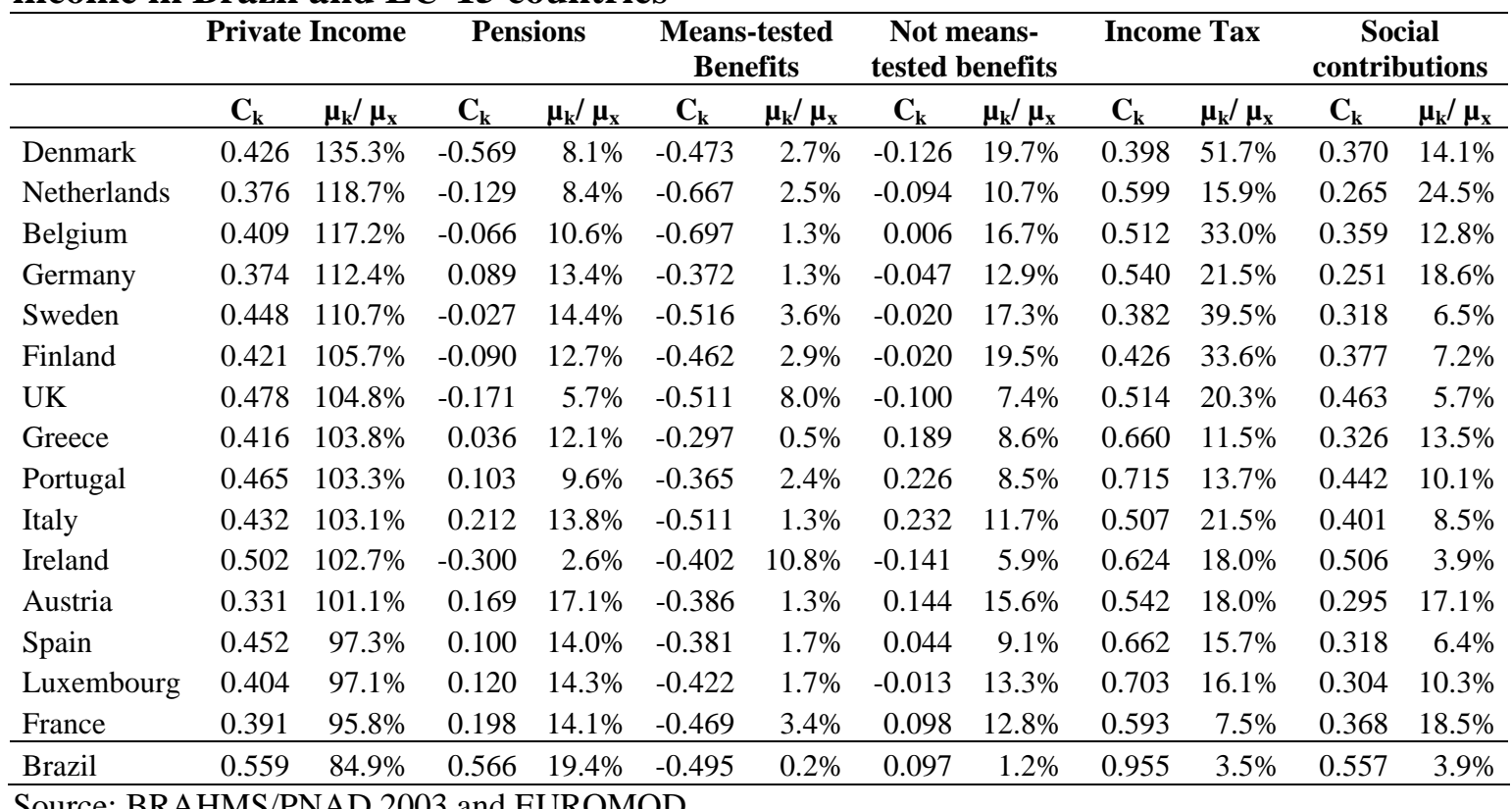

Table 9. Gini coefficients for different income definitions in Brazil and EU-15 countries

\begin{tabular}{lcccc}
\hline & Private Income & $\begin{array}{c}\text { Private Income } \\
\text { plus pensions } \\
\text { (PPI) }\end{array}$ & Gross Income & $\begin{array}{c}\text { Disposable } \\
\text { Income }\end{array}$ \\
\hline Finland & & 0.400 & 0.299 & (DI) \\
Denmark & 0.482 & 0.400 & 0.301 & 0.246 \\
Austria & 0.457 & 0.353 & 0.287 & 0.235 \\
Luxembourg & 0.441 & 0.396 & 0.319 & 0.233 \\
Belgium & 0.481 & 0.399 & 0.323 & 0.256 \\
Germany & 0.462 & 0.383 & 0.313 & 0.250 \\
France & 0.470 & 0.402 & 0.319 & 0.259 \\
Sweden & 0.486 & 0.423 & 0.327 & 0.287 \\
Netherlands & 0.501 & 0.362 & 0.295 & 0.299 \\
UK & 0.412 & 0.464 & 0.353 & 0.250 \\
Ireland & 0.502 & 0.495 & 0.376 & 0.313 \\
Spain & 0.516 & 0.433 & 0.372 & 0.324 \\
Portugal & 0.520 & 0.457 & 0.406 & 0.328 \\
Greece & 0.514 & 0.401 & 0.363 & 0.358 \\
Italy & 0.474 & 0.434 & 0.384 & 0.331 \\
\hline Brazil & 0.497 & 0.561 & 0.552 & 0.352 \\
\hline Source: BRAHMS/PNAD & 0.609 & 0.538 \\
\hline
\end{tabular}


Table 10. Poverty efficiency of non-pension benefits in Brazil and EU-15 countries

\begin{tabular}{|c|c|c|c|c|}
\hline & $\begin{array}{c}\text { Vertical Expenditure } \\
\text { Efficiency } \\
\text { (VEE) }\end{array}$ & $\begin{array}{c}\text { Poverty Reduction } \\
\text { Efficiency } \\
\text { (PRE) } \\
\end{array}$ & $\begin{array}{c}\text { Spillover } \\
\text { (S) } \\
\end{array}$ & $\begin{array}{c}\text { Poverty Gap } \\
\text { Efficiency } \\
\text { (PGE) } \\
\end{array}$ \\
\hline Finland & 0.4809 & 0.2693 & 0.4401 & 0.9270 \\
\hline Denmark & 0.4879 & 0.2691 & 0.4485 & 0.9070 \\
\hline Luxembourg & 0.5369 & 0.3240 & 0.3966 & 0.8915 \\
\hline France & 0.5403 & 0.3120 & 0.4226 & 0.8819 \\
\hline UK & 0.7178 & 0.5714 & 0.2039 & 0.8690 \\
\hline Netherlands & 0.5515 & 0.3425 & 0.3790 & 0.8457 \\
\hline Austria & 0.4791 & 0.2458 & 0.4870 & 0.8419 \\
\hline Ireland & 0.6636 & 0.5768 & 0.1308 & 0.8356 \\
\hline Belgium & 0.4486 & 0.2927 & 0.3475 & 0.8016 \\
\hline Germany & 0.4830 & 0.3147 & 0.3483 & 0.7390 \\
\hline Sweden & 0.4816 & 0.2742 & 0.4305 & 0.7149 \\
\hline Portugal & 0.5132 & 0.3382 & 0.3411 & 0.6426 \\
\hline Spain & 0.5980 & 0.3795 & 0.3654 & 0.6189 \\
\hline Italy & 0.4210 & 0.2542 & 0.3962 & 0.5792 \\
\hline Greece & 0.4925 & 0.2698 & 0.4522 & 0.4584 \\
\hline Brazil & 0.3511 & 0.3055 & 0.1298 & 0.0988 \\
\hline
\end{tabular}

Figure 1 Tax Burden and Gini Coefficient

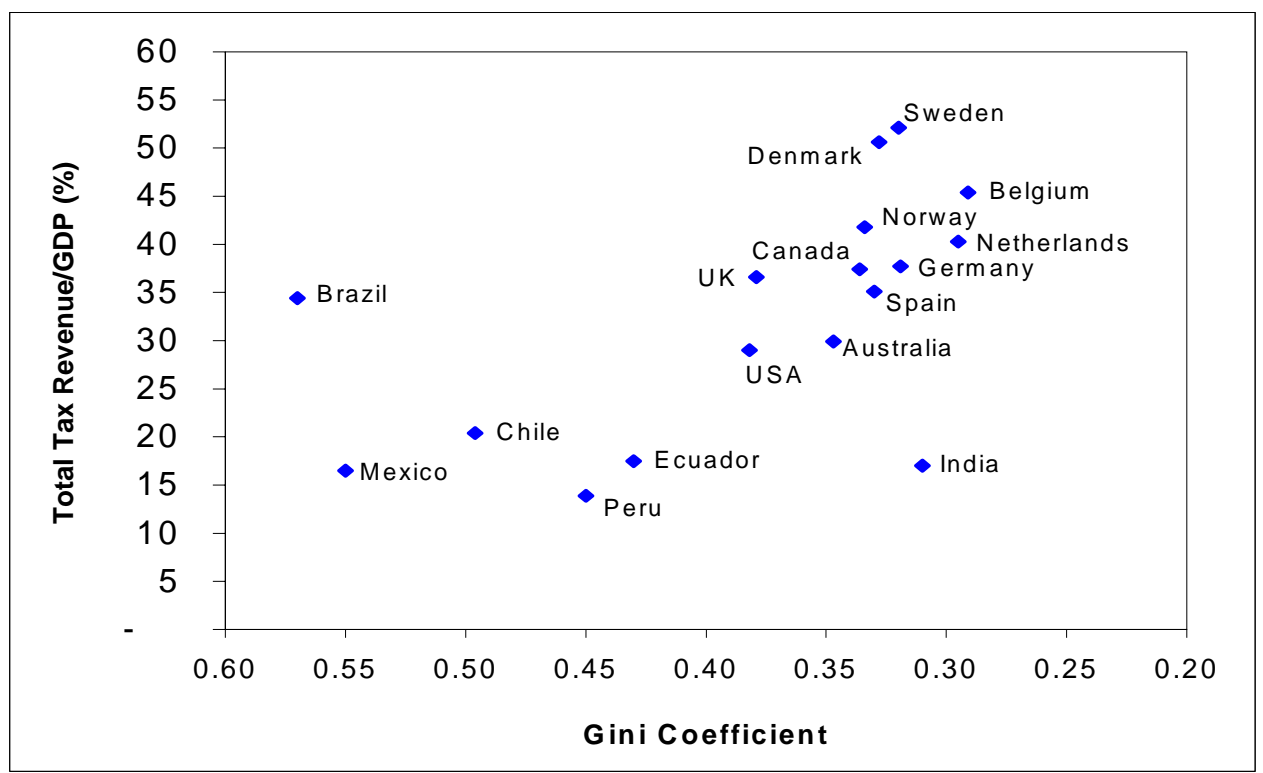

Source: Siqueira, Nogueira e Levy (2003) 
Figure 2. The Efficiency of Social Assistance

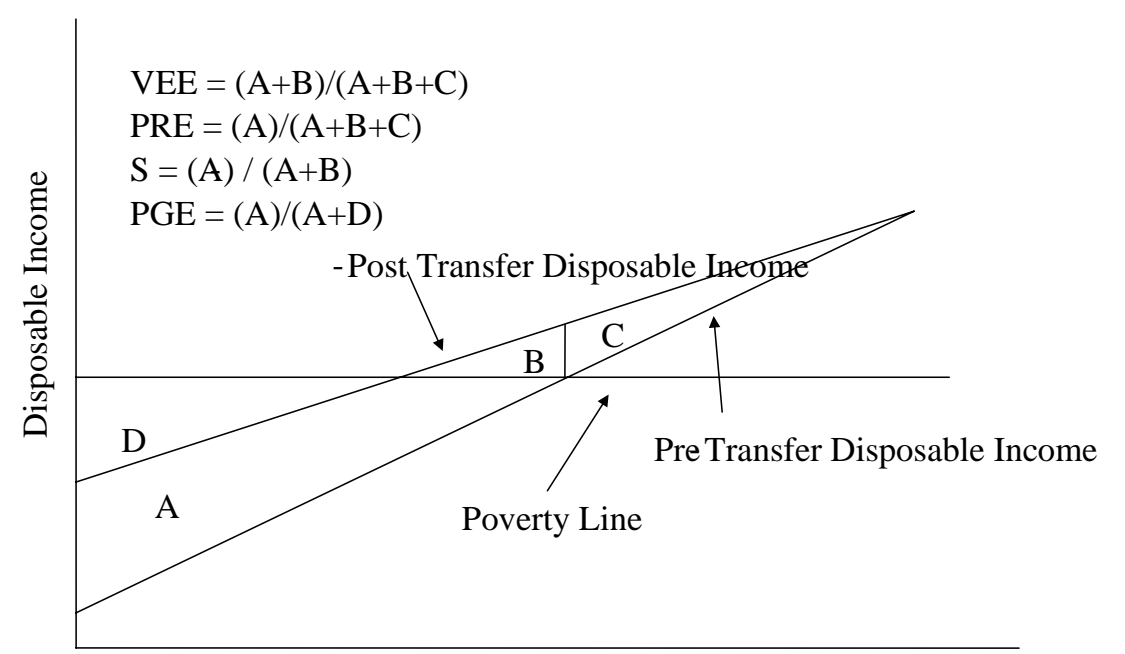

Households Ranked by Disposable Income 


\section{APPENDIX}

Table A1. Tax and benefit aggregates in Brazil 2003.

\begin{tabular}{|c|c|c|c|c|}
\hline & $\begin{array}{c}\text { Recipients } \\
\text { and } \\
\text { Taxpayers } \\
\text { (in thousands) }\end{array}$ & $\begin{array}{c}\text { Cash } \\
\text { Benefit } \\
\text { Spending } \\
\text { (\% of spending) }\end{array}$ & $\begin{array}{c}\text { Tax } \\
\text { Revenue } \\
\text { (\% of revenue) }\end{array}$ & $\begin{array}{c}\text { Tax/benefit } \\
\text { aggregates } \\
\text { (\% of GDP) }\end{array}$ \\
\hline Cash Benefits & 27,836 & 100.00 & & 13.04 \\
\hline Pensions & 20,449 & 84.75 & & 11.05 \\
\hline Private sector workers & 17,493 & 46.94 & & 6.12 \\
\hline Civil Servants & 2,956 & 31.29 & & 4.08 \\
\hline Annual Bonus & 20,449 & 6.52 & & 0.85 \\
\hline Contributory benefits & - & 11.32 & & 1.48 \\
\hline Unemployment Benefit & 4,903 & 3.21 & & 0.42 \\
\hline Salary Bonus & 7,862 & 0.89 & & 0.12 \\
\hline Family Benefit & 5,074 & 0.53 & & 0.07 \\
\hline Maternity benefit & 60 & 0.59 & & 0.08 \\
\hline Accident benefit & 265 & 0.41 & & 0.05 \\
\hline Sick leave & 1,089 & 3.96 & & 0.52 \\
\hline Other & 629 & 1.74 & & 0.23 \\
\hline $\begin{array}{l}\text { Non-contributory benefits } \\
\text { Old-age and disability }\end{array}$ & 7,387 & 3.93 & & 0.51 \\
\hline assistance benefits & 2,330 & 2.22 & & 0.29 \\
\hline Bolsa escola & 5,056 & 0.70 & & 0.09 \\
\hline Other means-tested ben. & 8,229 & 1.00 & & 0.13 \\
\hline Taxes & - & & 100.00 & 34.88 \\
\hline Income Tax & - & & 18.38 & 6.41 \\
\hline Personal Income Tax & 6,000 & & 9.19 & 3.21 \\
\hline Corporate Income Tax & - & & 9.19 & 3.21 \\
\hline Social Contributions & 34,950 & & 18.46 & 6.44 \\
\hline Payroll taxes & & & 5.54 & 1.93 \\
\hline VAT & & & 22.16 & 7.73 \\
\hline Other indirect taxes & & & 9.84 & 3.43 \\
\hline Property Tax & & & 2.80 & 0.98 \\
\hline Other & & & 22.82 & 7.96 \\
\hline
\end{tabular}

Table A2. Numbers of recipients/payers and cost/revenue of benefits/taxes in 2003: BRAHMS simulations compared with external statistics

\begin{tabular}{|c|c|c|c|c|c|c|}
\hline & \multicolumn{3}{|c|}{$\begin{array}{l}\text { Number of Taxpayers/Recipients } \\
\text { (in thousands) }\end{array}$} & \multicolumn{3}{|c|}{$\begin{array}{l}\text { Overall revenue/expenditure } \\
\text { (in billions of reais) }\end{array}$} \\
\hline & $\begin{array}{c}\text { External } \\
\text { Statistics } \\
\text { (A) }\end{array}$ & $\begin{array}{l}\text { BRAHMS } \\
\text { Estimates } \\
\text { (B) }\end{array}$ & $\begin{array}{c}\text { Ratio } \\
\text { (B)/ (A) }\end{array}$ & $\begin{array}{c}\text { External } \\
\text { Statistics } \\
\text { (C) }\end{array}$ & $\begin{array}{l}\text { BRAHMS } \\
\text { Estimates } \\
\text { (D) }\end{array}$ & $\begin{array}{l}\text { Ratio } \\
\text { (D)/ (C) }\end{array}$ \\
\hline $\begin{array}{l}\text { Pensions + Annual Bonus } \\
+ \text { Old-age assistance }\end{array}$ & 22,149 & 21,580 & $97 \%$ & 172.0 & 162.1 & $94 \%$ \\
\hline Unemployment Benefit & 4,903 & 3,217 & $66 \%$ & 6.5 & 4.7 & $72 \%$ \\
\hline Family Benefit & 5,074 & 6,003 & $118 \%$ & 1.1 & 1.6 & $154 \%$ \\
\hline Bolsa Escola & 5,056 & 4,449 & $88 \%$ & 1.4 & 1.2 & $84 \%$ \\
\hline Social Contrib (Workers) & 34,950 & 34,057 & $97 \%$ & 30.3 & 29.4 & $97 \%$ \\
\hline Income Tax & 6,000 & 6,348 & $106 \%$ & 25.5 & 26.0 & $102 \%$ \\
\hline
\end{tabular}

Sources: OECD (2005a), Ministry of the Economy (2005) and Ministry of Social Security (2005), and BRAHMS/PNAD 